\title{
Evaluation of Centromer H Protein (CENPH) Gene Expression in Prostate Cancers
}

\author{
Prostat Kanserlerinde Sentromer H Protein (CENPH) \\ Ekspresyonunun Değerlendirilmesi
}

\author{
Ilknur Karalezli ${ }^{\mathbb{( 1}}$, Ayse Gul Zamani ${ }^{2}$, Yunus Emre Goger ${ }^{3}$, Huseyin Osman Yilmaz ${ }^{1}$, Giray Karalezli ${ }^{(\mathbb{D}}$
}

\begin{abstract}
${ }^{1}$ Selcuk University, Vocational School of Health Services, Medical Laboratory Techniques Program, Department of Medical Services and Techniques, Konya, Turkey ${ }^{2}$ Necmettin Erbakan University, Meram Faculty of Medicine, Department of Medical Genetics, Konya, Turkey

${ }^{3}$ Necmettin Erbakan University, Meram Faculty of Medicine, Department of Urology, Konya, Turkey
\end{abstract}

Address correspondence to: Yunus Emre Goger, Necemetin Erbakan University, Meram Faculty of Medicine, Department of Urology, Konya, Turkey

e-mail: dr_yegoger@yahoo.com

Geliş Tarihi/Received: 12 November 2020 Kabul Tarihi/Accepted: 20 March 2021

\begin{abstract}
Öz
Amaç: Bu çalışmada amacımız, prostat kanserinde (PCa) sentromer H protein (CENPH) gen ekspresyon düzeylerinin değişip değişmediğini belirlemektir.

Hastalar ve Yöntem: Çalışmada 40 primer prostat kanserli hastanın prostat doku örneği kullanıldı. Bu nedenle, prostat kanseri teşhisi konmuş hastalardan çıkarılan toplam parafine gömülü prostat dokularında CENPH geninin transkripsiyonel analizi gerçekleştirildi. Ekspresyon analizleri, aynı hastanın prostat dokusundaki tümöral ve tümöral olmayan alanlardaki ekspresyonların karşılaştırılmasından elde edildi. Ayrı RNA izolasyonu yapıldı. Sonraki qRT-PZR analizleri üç kez tekrarlandı ve elde edilen veriler üzerinde Ct değerlerinin kalite kontrolleri yapıldı. Housekeeping geni GAPDH ve hedef gen CENPH'ın Ct değerleri doku (tümör ve normal) ve teknik tekrar gruplarında karşılaş̧ırıldı.

Bulgular: Prostat kanserinde tümör ve normal doku örnekleri arasında CENPH ekspresyonunda istatistiksel olarak anlamlı bir fark yoktu. Ayrıca ölüm nedenleri araştırılırken hastaların hiçbirinde $\mathrm{PCa}$ ya bağlı ölüm saptanmadı.

Sonuç: Çalışmamızda, CENPH gen ekspresyon anomalilerinde prostat kanseri tümörogenezi ile herhangi bir iliş̧i bulamadık. Bununla birlikte, yüksek CENPH gen ekspresyonuna sahip bazı kanserler (küçük hücreli olmayan akciğer kanseri, kolon kanseri vb.), tümör invazyonu, kötü prognoz ve ilaç direnci ile ilişkilidir. CENPH gen ekspresyonu ve prostat kanseri üzerindeki etkisi hakkında daha fazla çalışmaya intiyaç vardır.
\end{abstract}

Anahtar Kelimeler: Prostat kanseri, sentromer H protein, kinetochore protein, sentromer kinetochore, sentromer proteini

\section{Abstract}

Aim: In the present study, the aim is to determine whether centromere protein $\mathrm{H}(\mathrm{CENPH})$ gene expression levels change in prostate carcinoma (PCa).

Patients and Methods: Prostate tissue sample of 40 patients with primary prostate cancer was used in the study. Hence, transcriptional analysis of the CENPH gene was conducted in the total paraffin embedded prostate tissues extracted from patients diagnosed with prostate cancer. The expression analyses were obtained from the comparison of the expressions within the tumoral and non-tumoral areas in the prostate tissue of the same patient.

Results: Separate RNA isolation was performed. Subsequent qRT-PCR analyzes were repeated three times and quality controls of the $\mathrm{Ct}$ values were performed on the obtained data. The $\mathrm{Ct}$ values of the expression of the housekeeping gene GAPDH and the target gene CENPH gene were compared in tissue (tumor and normal) and technical repeat groups. There was no statistically significant difference in CENPH gene expression between tumor and normal tissue specimens in prostate cancer. Moreover, on investigating the causes of death, in none of the patients PCa related death was determined.

Conclusion: In our study, we could not find any relationship with prostate cancer tumorogenesis in CENPH gene expression anomalies. However, some cancers (non-small cell lung cancer, colon cancer, etc) with high CENPH gene expression are associated with tumor aggressiveness, poor prognosis and drug resistance. More studies are needed on CENPH gene expression and its effect on prostate cancer.

Key words: Prostate cancer, centromere protein $\mathrm{H}$, kinetochore protein, centromere kinetochore, centromere protein

Cite this article as: Karalezli I, Zamani AG, Goger YE, Yilmaz HO, Karalezli G. Evaluation of Centromer H Protein (CENPH) Gene Expression in Prostate Cancers. Selcuk Med J 2021;37(2): 151-157

Disclosure: None of the authors has a financial interest in any of the products, devices, or drugs mentioned in this article. The research was not sponsored by an outside organization. All authors have agreed to allow full access to the primary data and to allow the journal to review the data if requested. 


\section{INTRODUCTION}

Prostate cancer (PCa) is the most common cancer in developed countries, especially in the western world, and has a significant share in cancer deaths (1-3). While these cancers are rarely seen before the age of 40-50 years, the incidence increases with age, and evidence of latent disease in approximately $3 / 4$ of male over 80 years is shown in the autopsies (3). It is the most common cancer diagnosed after skin cancer in USA and the risk of a man have PCa from birth to death was reported to be $15.3 \%(1 / 7)$. This rate is $7.6 \%(1 / 13)$ for lung cancer (4). Approximately 233,000 new cases of PCa are expected in the USA in $2014,27 \%$ of all expected cancers (4). In addition, 280.000 deaths are expected in 2015, 350.000 new cases in 2025, and in the year $203070.000 \mathrm{PCa}$ deaths are expected (3). These figures show how $\mathrm{PCa}$ is an important health problem for an aging male. The incidence and mortality rate of $\mathrm{PCa}$ varies between different geographical areas. But, the natural course of $\mathrm{PCa}$ and the factors that affect it have not been fully elucidated. So, prognostic parameters are used to predict the natural course of the disease.

The most important prognostic parameters in organ limited disease are; Gleason score, capsule invasion, PSA, tumor progression and aneuploidy (2). Changes in the molecular basis of the neoplastic genome have been successfully associated with prognostic parameters such as risk of recurrence, treatment response, diseased or disease-free survival of various malignancies such as breast and lung carcinomas, gliomas and chronic leukemia in recent years. Molecular prognostic markers that can be used for these purposes in the prostate adenocarcinoma and intensive studies continue to determine the physiological processes that can be targeted for patient-specific therapy (5). The aim of our study is to determine the expression level of centromere protein $\mathrm{H}(\mathrm{CENPH})$ gene in prostate carcinoma.

\section{PATIENTS AND METHODS}

\section{Creation of Patient Groups and Collection of Tissue Samples}

A paraffin-blocked prostate tissue sample of 40 patients with primary $\mathrm{PCa}$ was used in the study. However, 9 tissue materials with high Gleason scores were later removed from 3 tissue materials because RNA was not isolated because the normal prostate tissue area was too closely related to the tumor tissue area removed from work. Evaluation Board's approval document dated June 30, 2010 and numbered
$2010 / 091$ is included in the study (Table 1).

The materials of the cases consisted of paraffin blocks which were followed by routine pathological procedure. According to the expert pathologist's assessment, 4 or 5 sections were taken from the area which is thought to belong to normal and abnormal tissues, which is believed to be the best of both tumors, separately from the pathology material was removed. Thus, sections of tumors taken from nontumor/normal tissue areas formed the control group of cases. The ages of the cases ranged from 50 to 89 and 21 of them were alive and 7 of them lost their lives. The cause of death in none of the deaths was related to $\mathrm{PCa}$.

\section{RNA Isolation from Parafine Embedded Tissue}

As a first step according to the EZ-RNA Total RNA Isolation Kit from the samples, removal of the wax was carried out. $1 \mathrm{ml}$ of xylol was placed in the tube containing the tissue sections, rinsed and allowed to stand at $70^{\circ} \mathrm{C}$ for 30 minutes. Centrifuged for 2 minutes at $5000 \mathrm{rpm}$ at $20^{\circ} \mathrm{C}$, supernatant was discarded. 750 $\mu \mathrm{l}$ of xylol was added to the pellet, vortexed, and this was left at $55^{\circ} \mathrm{C}$ for 30 minutes. It was centrifuged at $5000 \mathrm{rpm}$ for 2 minutes at $20^{\circ} \mathrm{C}$ and the supernatant

Table 1. Patient Gleason Scores, Age and Vital Data

\begin{tabular}{|c|c|c|c|}
\hline Number & Age & GS & Survive $\left({ }^{*}\right)$ \\
\hline$\overline{1}$ & 67 & $3+4$ & + \\
\hline 2 & 60 & $3+3$ & + \\
\hline 3 & 73 & $3+3$ & - \\
\hline 4 & 64 & $3+4$ & + \\
\hline 5 & 76 & $4+5$ & - \\
\hline 6 & 72 & $3+5$ & - \\
\hline 7 & 78 & $3+3$ & + \\
\hline 8 & 76 & $3+5$ & + \\
\hline 9 & 78 & $4+3$ & + \\
\hline 11 & 89 & $2+3$ & - \\
\hline 12 & 71 & $3+3$ & + \\
\hline 14 & 83 & $3+3$ & + \\
\hline 15 & 50 & $3+3$ & + \\
\hline 19 & 68 & $3+3$ & + \\
\hline 20 & 57 & $3+3$ & + \\
\hline 21 & 69 & $5+4$ & + \\
\hline 22 & 71 & $3+2$ & + \\
\hline 23 & 64 & $3+4$ & + \\
\hline 24 & 74 & $3+4$ & - \\
\hline 26 & 59 & $3+3$ & + \\
\hline 30 & 84 & $3+3$ & + \\
\hline 33 & 59 & $4+3$ & + \\
\hline 34 & 69 & $3+3$ & + \\
\hline 36 & 77 & $4+4$ & - \\
\hline 37 & 78 & $5+4$ & + \\
\hline 38 & 66 & $3+3$ & + \\
\hline 39 & 77 & $3+3$ & - \\
\hline 40 & 73 & $3+3$ & + \\
\hline
\end{tabular}


above was discarded. $1 \mathrm{ml}$ of $\mathrm{dH}_{2} \mathrm{O}$ was placed on the pellet and allowed to stand at $55^{\circ} \mathrm{C}$ for 5 minutes. Centrifuged at $10,000 \mathrm{rpm}$ for 5 minutes at $20^{\circ} \mathrm{C}$ and the supernatant above was discarded. $1 \mathrm{ml}$ of $\mathrm{dH}_{2} \mathrm{O}$ was placed on the pellet and allowed to stand at $55^{\circ} \mathrm{C}$ for 2 minutes. Centrifuged at $10,000 \mathrm{rpm}$ for 5 minutes at $20^{\circ} \mathrm{C}$ and the supernatant above was discarded. $1 \mathrm{ml}$ of $\mathrm{dH}_{2} \mathrm{O}$ was added to the pellet and centrifuged at $10,000 \mathrm{rpm}$ for 5 minutes at $20^{\circ} \mathrm{C}$ without being allowed to incubate. The supernatant above was discarded. In this way the paraffin was removed from the tissue. For preparation of Solution A $1.25 \mathrm{ml}$ $(1250 \mu \mathrm{l})$ of nuclease-free sterile water was diluated to $70 \mathrm{mg}$ of the solution. The enzyme was completely dissolved by gentle shaking. The reconstituted enzyme was stored at $-20^{\circ} \mathrm{C}$. SNP RNA Isolation System was used for RNA isolation and isolation was performed according to the following procedure. $500 \mu$ l solution $B$ on the pellet was vortexed by addition to $20 \mu \mathrm{l}$ of the solution and the product was left to incubate overnight at $45^{\circ} \mathrm{C}$. After incubation, $500 \mu \mathrm{l}$ solution $\mathrm{C}$ was added to the samples and vortexed.

This process was continued until a mixture of milk color and consistency was obtained. Samples were centrifuged at $20^{\circ} \mathrm{C}$ for 5 minutes at $10000 \mathrm{rpm}$. After centrifugation, approximately $500 \mu \mathrm{l}$ of clear supernatant was transferred to clean ependorf tubes. Add $600 \mu \mathrm{L}$ Solution D onto the tube and gently shake the tube and allow to sit for 1 hour in a dark place. The supernatant above was centrifuged at $20^{\circ} \mathrm{C}$ for 10 minutes at $10,000 \mathrm{rpm}$. After the supernatant was poured into Solution $\mathrm{D}, 50 \mu \mathrm{L}$ of Solution $\mathrm{E}$ was added. It was vortexed and centrifuged at $20^{\circ} \mathrm{C}$ for 5 minutes at $10000 \mathrm{rpm}$. After vortexing, the supernatant was poured out and the mouths of the tubes were left to dry for about 30-60 minutes at room temperature in a clean place. $100 \mu \mathrm{l}$ PCR Grade water was placed on the dried samples. Nanodropta measurements were made and the RNA concentration was diluted to 1000 $\mathrm{ng} / \mathrm{ml}$ and then stored at $-80^{\circ} \mathrm{C}$. After this step the RNAs became ready for use.

\section{Expression Analysis with Real Time PCR (Real Time Polymerase Chain Reaction)}

One-Run RT-QPCR kit (trademark) was used for real-time PCR. This kit is also a kit that allows both cDNA synthesis and polymerase chain reaction to occur in the same process without the need for cDNA synthesis. Seperately, it contains M-MLV reverting transcriptase to reduce RNAase activity during the reverse transcription step. After cDNA synthesis, Hotstart Taq DNA polymerase is activated at $95^{\circ} \mathrm{C}$ for 10 min. Glyceraldehyde 3-phosphate dehydrogenase (GAPDH) gene was studied as a house-keeping gene with CENPH gene for real-time PCR. The primers and progenies used for these genes are as follows (Table 2). FAM for the CENPH gene and JOE for the GADPH gene were used in the reaction. During the PCR phase of the study, the SNP One-RunRTQPCR kit was used. PCR mixes were prepared with the quantities given below for each gene and sample. CENPH Primer 1 (P1) 0.5 pmol, CENPH Primer 2 (P2) $0.5 \mathrm{~mol}, \mathrm{CENPH}$ Prob $0.3 \mathrm{pmol}$, RT/Hot Start Top Mix $0.3 \mathrm{ml}$, PCR Grade Water $6 \mathrm{ml}$, RNA Example 1 \& quot; $8 \mathrm{ml}$, Total Volume $30 \mathrm{ml}$

For the samples in the CENPH region, $19 \mu \mathrm{L}$ qPCR Reaksiymic (including $0.2 \mu \mathrm{M}$ each) dNTP and $2 \mu \mathrm{M} \mathrm{MgCl} 2$ were included. (3) 0.3 pmol CENP-H probe, (4) $0.3 \mu \mathrm{l}$ RT/Hot Start Taq enzyme mix (1) 0.5 pmol CENPH $\mathrm{P}_{1}$, (2) 0.5 pmol CENP- and (5) $8 \mu \mathrm{l}$ of isolated RNA. PCR Grade water was added, with a total volume of $30 \mu \mathrm{L}$, mixed gently by pipetting. For each sample in the GADPH region; $19 \mu \mathrm{l}$ qPCR Reaction Mix (dNTP and $2 \mathrm{mM} \mathrm{MgCl}$ with $2 \mathrm{mM}$ each). (1) 0.5 pmol GADPH P 1, (2) 0.5 pmol GADPH P 2, (3) 0.3 pmol GADPH Prob, (4) dNTP and $2 \mu \mu$ $\mathrm{MgCl} 2$,) $0.3 \mu \mathrm{l} \mathrm{RT/Hot} \mathrm{Start} \mathrm{Taq} \mathrm{Enzyme} \mathrm{Mix,} \mathrm{and}$ (5) $8 \mu$ l Isolated RNA was prepared. PCR Grade water was added, with a total volume of $30 \mu$, mixed gently by pipetting. Evaluation of expression results: The 2- $(\Delta \Delta \mathrm{Ct})$ formulation was used to determine the level of expression (6). The results were evaluated by comparing the tumor tissue expression in folds.

Table 2. CENPH and Glyceraldehyde 3-phosphate dehydrogenase (GAPDH) Genes Primers and Probes

\begin{tabular}{llll}
\hline Gen & Gen Bank No & Primer & Prob \\
\hline CENPH & NC_000005.10 & P1:GAACCTTATTTTGGGG & Farm_AGGATCCTGCCCTT \\
& & AGTAAAGTC & \\
& P2:GACAGACAAATGCACA & \\
GDPH & GAAGTATTC & Joe_AGGTCATCCATGACAACTTTGGY \\
& NC_00001:.12 & ACCTGCACCACCAACT & \\
& & P2:CATCACACACCACAGYTT & \\
& & YCCAGAG & \\
\hline
\end{tabular}


The 2- $(\Delta \Delta \mathrm{Ct})$ value was calculated when the level of expression was determined. $\mathrm{Ct}=$ number of cycles in which the fluorescent signal crosses the threshold value, $2-(\Delta \Delta \mathrm{Ct})=$ expression level in tumor tissue indicates how many folds in normal tissue expression.

$$
\begin{array}{ll}
\Delta \Delta C t= & \Delta C t \text { (tumor) }-\Delta C t(\text { normal) } \\
\Delta C t(\text { tumor })= & C t(C E N P H)-C t(G A P D H) \\
\Delta C t \text { (normal) }= & C t(C E N P H)-C t(G A D P H)
\end{array}
$$

As a result, for each case, a 2- $(\Delta \Delta \mathrm{Ct})$ value was calculated from the $\mathrm{Ct}$ value of both the tumor tissue and the normal tissue, so that the expression in the tumor tissue of each case was found to be the number of folds in the normal tissue. For each case and example, the real-time PCR phase was repeated three times and the average of three runs was taken. In the statistical analysis of qRT-PCR data, the $\mathrm{Ct}$ values were compared in the tissue (tumor and normal) and the technical repeat (repeat-1, -2 and -3) groups. The data were normalized according to the method described by Livak and Schmittengen (6). The statistical analysis of the normalized data in the control and tumor groups and the groups were analyzed in a factorial design pattern, and the results were analyzed using the "Minimum Significant Difference" (LSD) were used in all analyzes and MINITAB version 14 and Genstat Release 7 software were used (7).

\section{RESULTS}

A paraffin-blocked prostate tissue sample of 40 patients with primary PCa were used in the study. Separate RNA isolation was performed from the tissue samples of the tumor of the remaining 28 cases and tissue samples of the normal tissue without tumor, and the samples were coded. Subsequent qRT-PCR analyzes were repeated three times and quality controls of the Ct values were performed on the obtained data. The Ct values of the expression of housekeeping gene GAPDH and the target gene CENPH were compared in tissue (tumor and normal) and technical repeat groups. GADPH Ct values were significantly lower in tumor tissues $(25.62 \pm 0.3182)$ than control tissues $(26.61 \pm 0.3182)(P=0.029)$. There

\begin{tabular}{|c|c|c|c|c|c|c|c|c|c|c|c|}
\hline \multicolumn{3}{|c|}{$\begin{array}{l}\text { GAPDH } \\
\text { Technical Repeat }\end{array}$} & \multicolumn{3}{|c|}{$\begin{array}{c}\text { CENPH } \\
\text { Normal } \\
\text { Technical Repeat }\end{array}$} & \multicolumn{3}{|c|}{$\begin{array}{c}\text { GAPDH } \\
\text { Tumor } \\
\text { Technical Repeat }\end{array}$} & \multicolumn{3}{|c|}{$\begin{array}{c}\text { CENPH } \\
\text { Tumor } \\
\text { Technical Repeat }\end{array}$} \\
\hline 1 & 2 & 3 & 1 & 2 & 3 & 1 & 2 & 3 & 1 & 2 & 3 \\
\hline 26,75 & 26,92 & 26,8 & 25,97 & 25,89 & 25,8 & 24,9 & 25,06 & 25,02 & 24,96 & 25,35 & 25,81 \\
\hline 28,9 & 28,91 & 28,82 & 27,04 & 27,07 & 26,76 & 27,34 & 26,91 & 26,87 & 25,96 & 26,23 & 25,93 \\
\hline 28,34 & 28,28 & 28,19 & 27,76 & 28,7 & 28,89 & 28,38 & 28,43 & 24,82 & 29,45 & 29,6 & 29,82 \\
\hline 23,13 & 22,83 & 22,9 & 22,08 & 21,92 & 22,42 & 21,98 & 23,76 & 22,28 & 23,73 & 22,69 & 23,58 \\
\hline 28,99 & 29,25 & 29,56 & 27,4 & 27,4 & 27,72 & 24,68 & 23,33 & 24,92 & 24,47 & 24,58 & 24,46 \\
\hline 27,44 & 27,34 & 27,39 & 27,48 & 27,55 & 27,43 & 27,78 & 27,72 & 27,9 & 27,91 & 27,26 & 27,3 \\
\hline 26,83 & 26,73 & 26,24 & 26,88 & 24,11 & 27,54 & 23,25 & 23,68 & 23,93 & 26,81 & 27,27 & 27,29 \\
\hline 27,01 & 27,29 & 27,19 & 25,83 & 25,33 & 24,36 & 29,86 & 29,82 & 29,71 & 29,67 & 29,6 & 29,85 \\
\hline 26,06 & 26,1 & 26,09 & 22,65 & 23,84 & 25,75 & 21,67 & 21,66 & 21,73 & 26,36 & 26,72 & 26,99 \\
\hline 23,54 & 23,49 & 23,97 & 25,79 & 25,6 & 25,38 & 23,38 & 20,63 & 21,56 & 24,67 & 24,66 & 23,42 \\
\hline 21,96 & 24,04 & 23,92 & 25,33 & 24,96 & 26,21 & 23,47 & 22,38 & 22,19 & 28,02 & 26,63 & 28,92 \\
\hline 28,06 & 28,18 & 28,17 & 26,35 & 25,19 & 26,29 & 27,42 & 27,67 & 27,65 & 27,67 & 27,54 & 27,96 \\
\hline 26,74 & 26,92 & 26,97 & 23,72 & 23,49 & 24,49 & 25,89 & 26,12 & 26,06 & 24,1 & 23,95 & 23,87 \\
\hline 28,74 & 28,43 & 28,27 & 25,41 & 25,56 & 27,39 & 23,59 & 24,49 & 24,66 & 28,95 & 29,35 & 29,01 \\
\hline 32,31 & 32,06 & 31,86 & 29,96 & 25,59 & 29,11 & 21,86 & 23,05 & 22,96 & 24,94 & 25,41 & 25,39 \\
\hline 31,03 & 30,71 & 31,28 & 31,5 & 31,48 & 31,63 & 30,82 & 30,89 & 30,66 & 28,96 & 29,21 & 28,94 \\
\hline 24,17 & 23,89 & 23,88 & 24,15 & 24,43 & 23,38 & 25,53 & 25,24 & 26,24 & 29,71 & 29,61 & 29,83 \\
\hline 31,43 & 31,15 & 31,39 & 26,65 & 28,72 & 27,58 & 26,99 & 27,42 & 30,91 & 29,95 & 30,18 & 30,95 \\
\hline 25,3 & 24,9 & 25,01 & 24,52 & 24,55 & 25,61 & 23,1 & 23,43 & 23,18 & 27,85 & 27,65 & 27,74 \\
\hline 24,99 & 24,2 & 24,63 & 21,96 & 19,69 & 21,8 & 24,22 & 24,46 & 24,23 & 22,69 & 23,68 & 23,11 \\
\hline 23,87 & 23,76 & 23,59 & 21,32 & 20,93 & 21,88 & 20,24 & 20,1 & 20,18 & 19,25 & 17,12 & 20,17 \\
\hline 27,62 & 25,59 & 27,41 & 27,45 & 28,46 & 28,07 & 25,97 & 25,86 & 25,59 & 23,43 & 23,7 & 24 \\
\hline 28,01 & 27,25 & 27,92 & 26,69 & 25,47 & 26,61 & 27 & 26,53 & 26,72 & 20,72 & 20,93 & 22,65 \\
\hline 22,38 & 22,19 & 22,19 & 17,46 & 17,58 & 18,67 & 23,9 & 23,77 & 23,9 & 22,09 & 21,66 & 21,66 \\
\hline 29,79 & 29,93 & 29,16 & 31,59 & 31,69 & 31,76 & 24,22 & 23,92 & 23,93 & 23,76 & 23,23 & 23,85 \\
\hline 27,89 & 27,52 & 27,49 & 28,64 & 28,16 & 28,49 & 25,96 & 25,95 & 25,82 & 27,04 & 27,03 & 27,31 \\
\hline 30,62 & 30,31 & 30,49 & 29,84 & 30,08 & 30,02 & 30,76 & 30,62 & 30,61 & 30,03 & 30 & 30,51 \\
\hline 26,74 & 26,46 & 26,5 & 26,09 & 25,78 & 26,25 & 27,95 & 27,36 & 27,32 & 27,32 & 27,27 & 27,34 \\
\hline
\end{tabular}
was no difference between groups and technical

Table 3. Results of qRT-PZR analyzes (Three Repeat) 


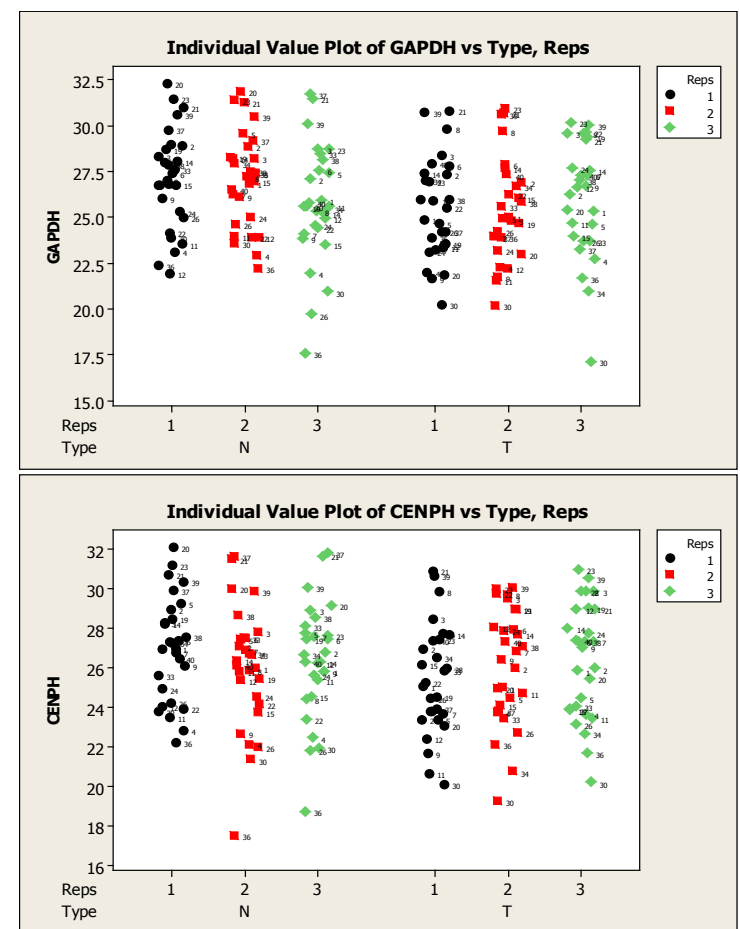

Figure 1. GAPDH (Left) and CENPH (Right) histograms of $\mathrm{Ct}$ values in normal $(\mathrm{N})$ and tumor $(\mathrm{T})$ tissues and in 3 different technical examinations $(1,2,3)$

replicates for the CENPH gene (Table 3).

In the analysis of qRT-PCR data, quality control of Ct values was performed first. So Residual analyzes and histograms (Table 1 and 2) were excluded from the study by deciding that samples 26,30 , and 36 were not suitable for further analysis. Further analysis was performed with tissue samples from a total of 25 remaining individuals. In the LSD analyzes, since the third technical repetition of GAPDH differs from the first two troughs, it was not taken into account in subsequent statistical analyzes (Figure 1,2). CENPH expression values were normalized by housekeeping GAPDH 2- $\Delta$ Ct- using broad expression values and groups were compared. CENPH gene expression is decreased in tumor tissues compared to normal tissues. However, the difference between the two groups was not statistically significant $(P=0.506)$.

\section{DISCUSSION}

The nature of prostate cancer is heterogeneous, and its clinical cours varies. Some prostate cancers may progress rapidly, develope metastasis on early stage, and could be mortal. However, the progression of some cancers is slow, and even if it is not treated it would show good clinical prognosis $(8,9)$. So, it is

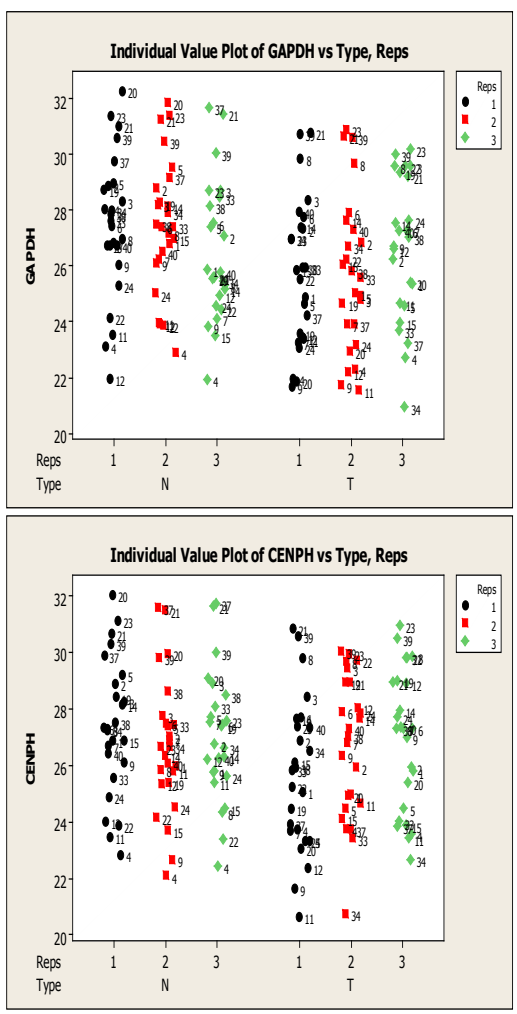

Figure 2. GAPDH (Left) CENPH (Right) histogram of Ct values $(n=25)$ in normal $(N)$ and tumor $(T)$ tissues and 3 different technical examinations $(1,2,3)$

of great importance that to identify molecular events and key factors that can determine or predict the behaviors of the tumor (10). For this purpose, genetic factors related to the prognosis of prostate cancer was investigated in many studies (11-13). Also, the genetic background and family history are related to a growing incidance of prostate cancer $(14,15)$. In this present study, we observed that the chromosomal instability may have been the result of mechanisms may be directly related to CENPH gene on prostate carcinogenesis.

Defects in the centromere and kinetochore function cause chromosome segregation to be inaccurate and chromosomal instability to occur. Chromosomal instability is therefore a phenomenon frequently occurring in the carcinogenesis process and is now accepted as one of the main features of human cancers (16). Kinetochores are a multi-protein complex in centromeres that are specialized structural regions of chromosomes and play an important role in the control point mechanism during cleavage (17). A large number of kinetochore components have recently been identified. One of these components, CENPH, 
co-localizes with CENP-A and CENP-C (18) on the outer part of the centromeric heterochromatin as a protein of the centromere-kinetochore complex along the cell cycle. Appropriate localization of the inner plate of the CENPH kinetochore complex is important for the proper separation of chromosomes and for the collection of multi-kinetochore proteins (19). There are several studies investigating the relationship between kinase proteins and carcinogenesis (20) found that cancer cells were up-regulated in human colectral lines of INNCP. CENP-F has been shown to be upregulated in head and neck squamous cell carcinoma (21). In the study of colorectal cancers, CENP-A was found to be overexpressed and targeted to the noncentromeric region (22). It has been found that CENP-A, which is overexpressed in HCT116 cell line studies, is localized to all chromosomes (23). CENPH has been reported to be associated with primary colorectal cancer (24), oral squamous carcinoma (25), nasopharyngeal carcinoma (19), esophageal carcinoma (26) and non-small cell lung cancer (27).

In the primary colorectal cancer study, it was found that CENPH is overexpressed in cancer tissue, and transplanted CENPH expressing plasmid into diploid cell lines induced aneuploidy (24). Researchers have concluded that aberrant expression and localization of CENPH play an important role in the development of aneuploidy frequently observed in colorectal cancers. Matsumoto et al. (2006) found that increased expression of CENPH in oral squamous cell carcinomas is associated with carcinogenesis. In the nasopharyngeal carcinoma cell (NPC) lines and immortalized nasopharyngeal epithelium cells, CENPH was exaggerated compared to normal nasopharyngeal epithelium cells and CENP-H expression was the prognostic indicator that could be an independent prognostic marker for survival of the patient (28). In a study of esophageal carcinoma, there was a difference in CENPH gene expression in patients grouped by sex, stage, and $T$ class in transcriptional and translational expression analyzes of CENPH gene in esophagial carcinoma, normal esophageal tissue, and immortalized esophageal cells. Studies have shown that patients with low CENPH gene expression have a longer life span than those with higher CENPH gene expression, and $\mathrm{CENPH}$ gene has been suggested to be an important marker for carcinoma follow-up in esophageal carcinoma patients (26).

CENPH gene expression in non-small cell lung cancer was found to be higher in both cancer cell lines and cancer tissues than normal cells and it was suggested that it could be used as a prognostic marker especially in early stage NSCLC (27). Matsumoto et al. (25) found that increased expression of CENPH gene in oral squamous cell carcinomas is associated with carcinogenesis. Aneuploidies and therefore chromosomal instability play an important role in the carcinogenesis in all types of cancer in which CENPH gene expression is being studied. In these studies, the fact that CENPH gene is overexpressed in cancerous tissues seems compatible with the chromosomal instability already present in the nature of these cancers. However, aneuploidy or polyploidies do not have a primary role in the carcinogenesis of prostate tissue we have studied in our study. The uncommon number of chromosomal irregularities leading to chromosomal instability in the prostate cancer tumorogenesis may in fact be a description of our inability to detect an increase in CENPH gene expression. The process leading to anomalies in CENPH expression from here seems to be invalid for prostate cancer tumorogenesis. High chromosomal instability in some cancer types is associated with tumor aggressiveness, drug resistance and poor prognosis. Three of these types of cancer (non-small cell lung cancer, colon cancer, and squamous cell cancer) are those in which CENPH expression is high. It is likely that the high expression of CENPH in these cancer types, where chromosomal instability is prevalent, may play a role in the pathogenesis of these cancers with hyperstabilizing kinetochoremicrotubule interactions from chromosomal instability mechanisms. Unfortunately, there are no prostate cancers in these 10 cancers that have chromosomal instability results. It may be thought that other tumors with high CENPH gene expression in prostate tumorogenesis, which are moving from the origin of tumoral heterogeneity, may be behaving differently from the tumorogenesis process.

Furthermore, chromosomal instability may have been the result of mechanisms other than mitotic control point defects, sister chromatid cohesion defects, and centrosome amplification another mechanism that may be directly related to $\mathrm{CENPH}$, even though it has a primary effect on prostate carcinogenesis. High expression of kinetochore components may lead to chromosomal instability by disrupting the normal kinetochore association. Of course, the correct dosage is also important for spindle-control signal transduction. Chromosomal instability also leads 
to an increase in the levels of proteins required for DNA replication, repair and mitosis, which facilitates the genetic modification of the process leading to cellular growth and transformation (29). It is seen that CENPH gene expression is increased in cancers with common chromosomal instability. This is associated with tumor aggressiveness.

Conflict of interest: Authors declare that there is no conflict of interest between the authors of the article.

Financial conflict of interest: Authors declare that they did not receive any financial support in this study.

Address correspondence to: Yunus Emre Goger, Necemetin Erbakan University, Meram Faculty of Medicine, Department of Urology, Konya, Turkey. 42080

Tel: + 905334150753 e-mail:dr_yegoger@yahoo.com

\section{REFERENCES}

1. Bostwick DG, Burke HB, Djakiew D, et al. Human prostate cancer risk factors: Interdisciplinary International Journal of the American Cancer Society. Cancer 2004;101(S10):2371490.

2. Buhmeida A, Pyrhönen S, Laato $M$, et al. Prognostic factors in prostate cancer. Diagn Pathol 2006;1(1):4.

3. Arcangeli S, Pinzi V, Arcangeli G. Epidemiology of prostate cancer and treatment remarks. World J Radiol. 2012;4(6):241.

4. Siegel R, Ma J, Zou Z, et al. Cancer statistics, 2014. CA Cancer J Clin 2014;64:9-29.

5. Gurel Z, Sieg KM, Shallow KD, et al. Retinal O-linked $\mathrm{N}$-acetylglucosamine protein modifications: Implications for postnatal retinal vascularization and the pathogenesis of diabetic retinopathy. Mol Vis 2013;19:1047.

6. Livak KJ, Schmittgen TD. Analysis of relative gene expression data using real-time quantitative PCR and the 2- $\triangle \triangle C T$ method. Methods 2001;25(4):402-8.

7. Payne JC, Rous BW, Tenderholt AL, et al. Spectroscopic determination of the binding affinity of zinc to the DNAbinding domains of nuclear hormone receptors. Biochemistry 2003;42(48):14214-24.

8. Albertsen PC, Hanley JA, Fine JJJ. 20-year outcomes following conservative management of clinically localized prostate cancer. JAMA 2005;293(17):2095-101.

9. Bill-Axelson A, Holmberg L, Ruutu $M$, et al. Radical prostatectomy versus watchful waiting in early prostate cancer. N Engl J Med 2011;364(18):1708-17.

10. Zu K, Martin NE, Fiorentino M, et al. Protein expression of PTEN, insulin-like growth factor I receptor (IGF-IR), and lethal prostate cancer: A prospective study. Randomized Controlled Trial 2013;22(11):1984-93.

11. Reid A, Attard G, Ambroisine L, et al. Molecular characterisation of ERG, ETV1 and PTEN gene loci identifies patients at low and high risk of death from prostate cancer. $\mathrm{Br}$ J Cancer 2010;102(4):678-84.

12. McMenamin ME, Soung P, Perera $S$, et al. Loss of PTEN expression in paraffin-embedded primary prostate cancer correlates with high Gleason score and advanced stage. Cancer Res 1999;59(17):4291-6.
13. Dreher $T$, Zentgraf $H$, Abel $U$, et al. Reduction of PTEN and p27 kip1 expression correlates with tumor grade in prostate cancer. Analysis in radical prostatectomy specimens and needle biopsies Virchows Arch 2004;444(6):509-17.

14. Jansson KF, Akre O, Garmo $\mathrm{H}$, et al. Concordance of tumor differentiation among brothers with prostate cancer Eur Urol 2012;62(4):656-61.

15. Hemminki KJWjou. Familial risk and familial survival in prostate cancer World J Urol 2012;30(2):143-8.

16. Bakhoum SF, Compton DA. Kinetochores and disease: Keeping microtubule dynamics in check! Current opinion in cell biology. Curr Opin Cell Biol 2012;24(1):64-70.

17. Fukagawa T. Assembly of kinetochores in vertebrate cells. Experimental cell research. Exp Cell Res 2004;296(1):21-7.

18. Sugata N, Munekata E, Todokoro K. Characterization of a novel kinetochore protein, CENP-H. J Biol Chem 1999;274(39):27343-6.

19. Liao WT, Wang $\mathrm{X}, \mathrm{Xu} \mathrm{LH}$, et al. Centromere protein $\mathrm{H}$ is a novel prognostic marker for human nonsmall cell lung cancer progression and overall patient survival. Cancer 2009;115(7):1507-17.

20. Adams RR, Eckley MD, Vagnarelli $P$, et al. Human INCENP colocalizes with the Aurora-B/AIRK2 kinase on chromosomes and is overexpressed in tumour cells. Chromosoma 2001;110(2):65-74.

21. Guardia Cdl, Casiano CA, Trinidad-Pinedo J, et al. Cenp-F gene amplification and overexpression in head and neck squamous cell carcinomas. Head and Neck 2001;23(2):10412.

22. Tomonaga T, MatsushitaK, YamaguchiS, etal. Overexpression and mistargeting of centromere protein-A in human primary colorectal cancer. Cancer Res 2003;63(13):3511-6.

23. Van Hooser AA, Ouspenski II, Gregson HC, et al. Specification of kinetochore-forming chromatin by the histone $\mathrm{H} 3$ variant CENP-A. J Cell Sci 2001;114(19):3529-42.

24. Tomonaga $\mathrm{T}$, Matsushita $\mathrm{K}$, Ishibashi M, et al. Centromere protein $\mathrm{H}$ is up-regulated in primary human colorectal cancer and its overexpression induces aneuploidy. Cancer Res 2005;65(11):4683-9.

25. Matsumoto Si, Yamazaki C, Masumoto K-h, et al. Abnormal development of the olfactory bulb and reproductive system in mice lacking prokineticin receptor PKR2. Proc Natl Acad Sci U S A .2006;103(11):4140-5.

26. Guo XZ, Zhang G, Wang JY, et al. Prognostic relevance of Centromere protein $\mathrm{H}$ expression in esophageal carcinoma. BMC cancer 2008;8(1):233.

27. Liao $\mathrm{WT}, \mathrm{Yu} \mathrm{CP}, \mathrm{Wu} \mathrm{DH}$, et al. Upregulation of CENP-H in tongue cancer correlates with poor prognosis and progression. J Exp Clin Cancer Res 2009;28(1):74.

28. Liao WT, Song LB, Zhang $\mathrm{HZ}$, et al. Centromere protein $\mathrm{H}$ is a novel prognostic marker for nasopharyngeal carcinoma progression and overall patient survival. Clin Cancer Res 2007;13(2):508-14.

29. Duesberg P, Rasnick D, Li R, et al. How aneuploidy may cause cancer and genetic instability. Anticancer Res 1999;19(6A):4887-906. 